\title{
PENGARUH IMPLEMENTASI THE 4-E LEARNING CYCLE TERHADAP PENGETAHUAN, KETERAMPILAN PROSES DASAR, DAN SIKAP ILMIAH IPA SISWA SDK KEREROBBO
}

\author{
THE EFFECT OF THE IMPLEMENTATION OF THE 4-E LEARNING CYCLE \\ ON THE KNOWLEDGE, BASIC PROCESS SKILLS AND SCIENTIFIC ATTITUDE \\ OF THE STUDENTS OF CHATOLIC ELEMENTARY SCHOOL KEREROBBO
}

\author{
Ferdinandus Bele Sole, Insih Wilujeng \\ STKIP Weetebula NTT, Universitas Negeri Yogyakarta \\ ferdibs@yahoo.com, insihuny@yahoo.co.id
}

\begin{abstract}
Abstrak
Penelitian ini bertujuan untuk mengetahui pengaruh model 4-E learning cycle terhadap: (1) pengetahuan IPA siswa SD, (2) keterampilan proses dasar IPA siswa SD, dan (3) sikap ilmiah IPA siswa SD. Penelitian ini merupakan penelitian eksperimen semu. Populasi dalam penelitian ini adalah seluruh siswa kelas V SDK Kererobbo, Kecamatan Kota Tambolaka semester II tahun ajaran 2012/ 2013. Pengambilan sampel dilakukan dengan teknik sampling jenuh untuk dijadikan sebagai kelas eksperimen dan kelas kontrol. Pada kelas eksperimen dilaksanakan pembelajaran IPA dengan menggunakan model 4-E Learning Cycle, sedangkan pada kelas kontrol menggunakan pembelajaran ekspositori. Instrumen yang digunakan adalah (1) tes terintegrasi untuk mengukur pengetahuan dan keterampilan proses dasar IPA dan (2) skala sikap untuk mengukur sikap ilmiah. Analisis data menggunakan (1) statistik deskriptif untuk mendeskripsikan data pengetahuan, keterampilan proses dasar dan sikap ilmiah; dan (2) statistik inferensial dengan menggunakan independent sampel t-test untuk menguji hipotesis penelitian pada taraf signifikansi 5\% $(\alpha=0,05)$. Hasil penelitian menunjukkan bahwa: (1) penerapan model 4-E learning cycle berpengaruh positif dan signifikan terhadap pengetahuan IPA siswa di SDK Kererobbo dengan nilai sig 0,044; (2) penerapan model 4-E learning cycle berpengaruh positif dan signifikan terhadap keterampilan proses dasar IPA siswa di SDK Kererobbo dengan nilai sig 0,020; dan (3) penerapan model 4-E learning cycle berpengaruh positif dan signifikan terhadap sikap ilmiah siswa di SDK Kererobbo dengan nilai sig 0,000.
\end{abstract}

Kata Kunci: the 4-E Learning Cycle, pembelajaran ekspositori, pengetahuan sains, keterampilan proses dasar, sikap ilmiah.

\begin{abstract}
This study aimed to know the effect of the 4-E learning cycle model on (1) the science knowledge of elementary school students, (2) basic process skills of elementary school students, and (3) scientific attitude of elementary school students. This study was quasi-experimental. The population was all students of class V SDK Kererobbo, District of Tambolaka City in the second semester of the academic year 2012/2013. The sample was established using the saturated sampling technique to serve as the experimental class and control class. The teaching in the experimental class was conducted using the 4-E Learning Cycle model, while in the control class used the expository learning. The instruments used were (1) an integrated test to measure the knowledge and skills of basic science process and (2) a scale of attitude to measure scientific attitude. The analysis of the data used (1) descriptive statistics to describe the data on knowledge, basic process skills, and scientific attitudes; (2) the inferential statistics using independent sample t-test to test the hypothesis at 5\% significance level $(\alpha=0.05)$. The results are as follows. (1) The implementation of the 4-E Learning Cycle model affects the science knowledge of the primary school students positively and significantly (sig 0.044). (2) The implementation of the 4-E Learning Cycle model affects the basic process skills of primary school students positively and significantly (sig 0.020). (3) The implementation of the 4-E Learning Cycle model affects scientific attitudes of primary school students positively and significantly (sig 0.000).
\end{abstract}

Keywords: the 4-E Learning Cycle, expository learning, knowledge of science, the basic process skills, scientific attitudes. 


\section{Pendahuluan}

Setiap jenjang pendidikan baik jenjang pendidikan dasar, pendidikan menengah, maupun pendidikan tinggi memiliki kurikulum tersendiri. Permendiknas no. 22 tahun 2006 menyebutkan bahwa kurikulum SD/MI memuat delapan mata pelajaran, muatan lokal, dan pengembangan diri (Depdiknas, 2006a). Kedelapan mata pelajaran tersebut adalah: Pendidikan Agama, Pendidikan Kewarganegaraan, Bahasa Indonesia, Matematika, Ilmu Pengetahuan Alam (IPA), Ilmu Pengetahuan Sosial (IPS), Seni Budaya dan Keterampilan (SBK) dan Pendidikan Jasmani, Olahraga dan Kesehatan (PJOK). Dengan melaksanakan pembelajaran dengan struktur kurikulum yang ada ini, diha-rapkan mampu mewujudkan fungsi dan tujuan pendidikan nasional.

Salah satu mata pelajaran yang terdapat dalam kurikulum Sekolah Dasar/Madrasah Ibtidaiyah adalah Ilmu Pengetahuan Alam (IPA). Tujuan pembelajaran IPA SD adalah mengembangkan pengetahuan dan pemahaman konsepkonsep IPA yang bermanfaat dan dapat diterapkan dalam kehidupan sehari-hari; mengembangkan rasa ingin tahu, sikap positif dan kesadaran tentang adanya hubungan yang saling mempengaruhi antara IPA, lingkungan, teknologi, dan masyarakat; mengembangkan keterampilan proses untuk menyelidiki alam sekitar, memecahkan masalah dan membuat keputusan (Depdiknas, 2006). Tujuan pembelajaran IPA di SD ini menyiratkan bahwa pembelajaran IPA mencakup berbagai aspek dan tidak hanya berorientasi pada pencapaian hasil belajar aspek kognitif saja. Aspek lain yang juga penting untuk dipahami adalah aspek keterampilan proses dalam mempelajari IPA dan aspek sikap serta aplikasinya dalam bidang lain atau dalam kehidupan sehari-hari.

Sulistyorini (2007, p.9) mengemukakan bahwa pada hakikatnya sains dapat dipandang dari segi produk, proses dan segi pengembangan sikap. Artinya, belajar sains memiliki dimensi proses, dimensi hasil (produk), dan dimensi pengembangan sikap ilmiah. Ketiga dimensi tersebut bersifat saling terkait. Ini berarti bahwa proses belajar mengajar IPA seharusnya mengandung ketiga dimensi tersebut.

Dalam implementasinya, pembelajaran IPA di SDK Kererobbo masih terfokus pada aspek produk saja yaitu muatan pengetahuan yang harus dikuasai oleh siswa seperti sejumlah fakta dan konsep. Aspek proses, sikap dan apli- kasi IPA belum sepenuhnya dilaksanakan oleh guru. Hal ini dapat dilihat dari proses pembelajaran dimana guru hanya berfokus pada pencapaian target ketuntasan materi pada setiap semester guna memenuhi tuntutan kurikulum. Selain itu, penilaian yang dilakukan untuk mengukur pencapaian siswa masih terbatas pada aspek kognitif saja dan menjadi kriteria keberhasilan siswa dalam mempelajari IPA. Hal ini tentu bertentangan dengan karakteristik IPA dalam Kurikulum Tingkat Satuan Pendidikan yang berorientasi holistik, baik pada penguasaan konsep, proses penemuan konsep, dan juga sikap ilmiah.

Berdasarkan hasil wawancara dengan guru IPA disebutkan bahwa salah satu faktor yang mempengaruhinya adalah pembelajaran IPA yang dilaksanakan selama ini masih menggunakan metode yang bersifat teacher centered dimana peran guru dalam pembelajaran seperti menjelaskan materi masih dominan dan belum mengoptimalkan penggunaan alat-alat peraga maupun kit IPA. Kenyataan ini mengakibatkan pembelajaran lebih bersifat satu arah, mengutamakan aspek pengetahuan dan mengabaikan aspek-aspek IPA lainnya seperti keterampilan proses dan sikap ilmiah. Selain itu, persepsi guru yang berusaha menyelesaikan materi ajar guna mencapai ketuntasan masih cenderung dimiliki oleh guru. Akibatnya adalah, walaupun berbagai metode telah digunakan, namun tetap berorientasi pada peran guru.

Faktor lain yang mempengaruhi adalah kurangnya pemahaman guru tentang modelmodel pembelajaran sains yang inovatif seperti model pembelajaran konstruktivisme, model pembelajaran terpadu (integrated), model children learning in science (CLIS), dan model pembelajaran siklus (learning cycle). Modelmodel pembelajaran ini memiliki fase-fase dalam implementasinya serta memiliki kelebihan kelemahannya tersendiri namun dapat mengembangkan kemampuan struktur kognitif untuk membangun pengetahuan sendiri melalui berpikir rasional.

Melihat kondisi seperti yang telah diuraikan maka perlu suatu perubahan paradigma yang lebih holistik dimana pembelajaran sains tidak hanya berorientasi pada aspek pengetahuan saja tetapi juga mempertimbangkan aspek keterampilan proses dan sikap ilmiah. Perubahan ini dapat dimulai dengan menerapkan model-model pembelajaran inovatif yang dapat merangkum ketiga aspek tersebut. Salah satu model yang dapat digunakan adalah model sik- 
lus belajar 4-E. Di SDK Kererobbo, model siklus belajar 4-E ini belum pernah diterapkan dan dikaji secara mendalam, termasuk belum diketahuinya pengaruh the 4-E learning cycle terhadap pengetahuan, keterampilan proses dasar, dan sikap ilmiah siswa terutama dalam pembelajaran IPA.

Teori yang melandasi model siklus belajar 4-E ini adalah teori konstruktivisme. Menurut teori ini, pengetahuan dibangun oleh siswa sendiri secara aktif dan siswa dapat belajar dengan melakukan sendiri (learning by doing themselves).

Teori konstruktivisme dapat diimplementasikan dengan menggunakan berbagai metode mengajar. Pendapat ini sesuai dengan Yilmaz (2006, p.2), constructivist theory can be implemented through many different teaching models or methods. One of them is 4-E (Exploration, Explanation, Expansion, Evaluation) Learning Cycle method which is based on Piaget's developmental theory. Teori Piaget yang dimaksud adalah teori tentang teori perkembangan kognitif yang dibagi dalam 4 tahapan yakni sensorimotor, praoperasional, operasional konkrit, dan operasional formal. Tahapan pada pembelajaran siklus 4-E ini disesuaikan dengan tahapan perkembangan siswa kelas $\mathrm{V}$ yang berada pada tahapan operasional konkrit.

Oren \& Ramazan (2009, p.1) dalam latar belakang penelitiannya juga mengungkapkan bahwa :

.... In this reason, in there needs new approaches which must aim to improve students' scientific process skills, logical thinking ability, creativity, critical thinking skills, positive attitude toward science. One of these approaches is the learning cycle.

Pendekatan siklus belajar sebagai salah satu pendekatan dalam pembelajaran diharapkan dapat mendukung peningkatan keterampilan proses ilmiah, keterampilan berpikir kritis dan sikap positif terhadap IPA.

Kajian tentang model siklus belajar 4-E ini tidak dapat dipisahkan dari pembelajaran siklus ((learning cycle) yang diperkenalkan oleh Robert Karplus. Menurut Turkmen (2006a, p.3), The learning cycle that introduced by Karplus and Thier (1967) has evolved into one of the most important teaching approaches in science education. Siklus belajar ini merupakan salah satu pendekatan pengajaran yang penting dalam pendidikan IPA. Pendekatan ini lebih bersifat student centered dibandingkan dengan metode lain yang lebih berorientasi pada buku teks.

Lawson (1987, pp.55-67) berpendapat bahwa siklus belajar sebagai tahapan-tahapan yang berbeda dalam mempelajari dan melakukan IPA. Siklus belajar juga mempengaruhi pencapaian dalam konten dan keterampilanketerampilan proses. Selain itu, banyak penelitian yang mengkaji pengaruh siklus belajar terhadap sikap, pencapaian isi serta keterampilan berpikir.

Model pembelajaran siklus belajar merupakan salah satu model pembelajaran yang dikembangkan untuk memberi kesempatan kepada siswa-siswi membangun pemahaman terhadap objek melalui serangkaian kegiatan yang berulang. Fokus pembelajaran tidak hanya ditekankan pada pemahaman konsep, tetapi lebih kepada proses perolehan konsep, perluasan, sampai pada aplikasi konsep dalam konteks yang nyata (Agus Sugianto, dkk., 2009, pp.311).

Menurut Turkmen (2006b, p.73), pendekatan siklus belajar merupakan sebuah pembelajaran berbasis penyelidikan atau inkuiri. Lebih lanjut diuraikan bahwa "learning cycle approach's goal is to enhance learning and provide students with more authentic science experience that imitate those real scientists and are in accordance with the nature of science". Tujuan pendekatan siklus belajar adalah untuk meningkatkan pembelajaran dan menyediakan bagi siswa dengan banyak pengalaman sains yang menyerupai ilmuwan sesungguhnya dan sesuai dengan sifat dasar IPA. Pengalamanpengalaman yang dimaksudkan merupakan aktivitas siswa dalam proses pembelajaran.

Hal yang sama juga diungkapkan oleh Madu dan Amaechi (2012, p.2) yang mengungkapkan bahwa pendekatan siklus belajar merupakan sebuah pendekatan mengajar berbasis inkuiri yang dapat bermanfaat bagi guru dalam merancang materi kurikulum dan strategi pengajaran IPA. Pendekatan ini bersifat students centered dengan banyak aktivitas yang disediakan seperti pengamatan dasar, pengumpulan data, analisis aktivitas, kejadian dan fenomena. Dengan adanya berbagai aktivitas yang dilakukan, tentu saja dapat melatih keterampilan proses yang dibutuhkan dalam pembelajaran IPA.

Pembelajaran siklus ini pada awalnya terdiri atas tiga fase yakni eksplorasi (exploration), penemuan (invention), dan aplikasi (application). Model ini pertama kali diperkenalkan 
oleh Robert Karplus pada tahun 1967. Namun dalam perkembangannya, model ini mengalami modifikasi sehingga memiliki ta-hapan atau fase yang variatif seperti The 4-E Science Learning Cycle, The 5 E Instructional Model dan The 7 E Instructional Model. Dalam penelitian ini, peneliti ingin mengkaji tentang pembelajaran siklus dengan empat tahapan.

Berdasarkan uraian di atas maka dapat disimpulkan bahwa The 4-E Learning Cycle adalah model pembelajaran yang menerapkan pembelajaran secara siklus yang diawali dengan tahap eksplorasi, eksplanasi, ekspansi dan evaluasi. Model pembelajaran siklus 4-E ini dilaksanakan secara terus menerus (kontinu) sehingga dapat menghasilkan prestasi yang luar biasa dalam IPA, kemampuan mengingat konsep yang lebih baik, sikap baik terhadap ilmu pengetahuan dan pembelajaran IPA, meningkatkan kemampuan penalaran dan keterampilan proses.

Sesuai dengan nama modelnya, pembelajaran siklus 4-E terdiri atas empat fase yakni eksplorasi (exploration), eksplanasi (explanation), ekspansi (expansion) dan evaluasi (evaluation). Setiap fase dalam siklus ini memiliki dukungan secara teoritis dari teori perkembangan kognitif oleh Jean Piaget dan menerapkan prosedur pembelajaran konstruktivistik. Secara siklus, mekanisme pembelajaran pada The 4-E Science Learning Cycle dapat dilihat pada gambar 1 .

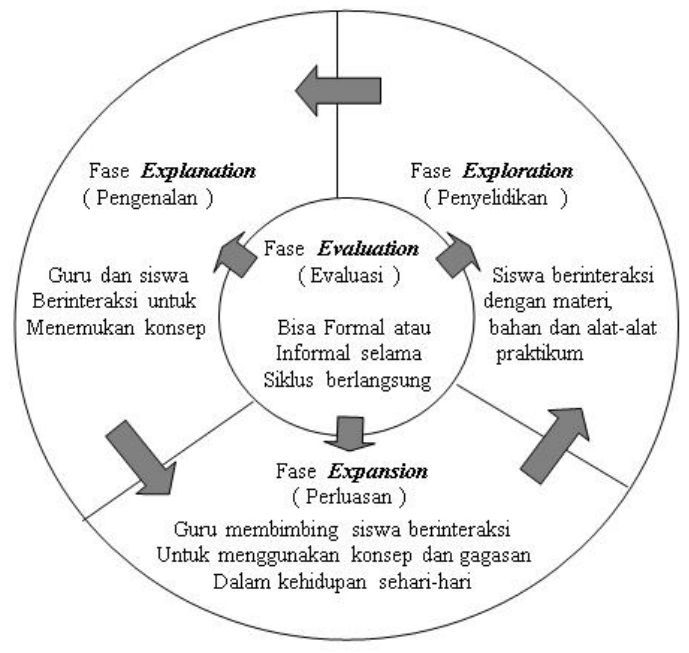

Gambar 1. Pembelajaran Siklus 4-E

\section{Metode}

Jenis Penelitian

Pendekatan penelitian ini adalah penelitian kuantitatif dengan jenis eksperimen semu (quasi experiment) dengan tujuan menguji se- buah perlakuan dengan membandingkan dua perlakuan berbeda kepada subjek penelitian. Pada kelompok eksperimen diberi perlakuan dengan menggunakan model pembelajaran 4-E Learning Cycle, sedangkan pada kelompok kontrol menggunakan model pembelajaran ekspositori.

Tempat dan Waktu Penelitian

Penelitian ini dilaksanakan di SDK Kererobbo yang terletak di Kecamatan Loura Kabupaten Sumba Barat Daya-NTT. Waktu pelaksanaan dimulai pada bulan September 2012 sampai April 2013. Penelitian ini dilakukan di kelas V pada semester genap tahun ajaran 2012/2013.

Populasi dan Sampel

Populasi dalam penelitian ini adalah seluruh siswa kelas V SDK Kererobbo, Kecamatan Kota Tambolaka semester II tahun ajaran 2012/2013. Pengambilan sampel dilakukan dengan teknik sampling jenuh untuk dijadikan sebagai kelas eksperimen dan kelas kontrol

Teknik dan Instrumen Pengumpulan Data

Teknik yang digunakan untuk mengumpulkan data dalam penelitian ini adalah tes dan non tes. Teknik tes terintegrasi digunakan untuk mengukur pencapaian pengetahuan dan keterampilan proses dasar IPA. Tes dilakukan untuk mengukur kemampuan awal siswa (pretest) dan mengukur kemampuan siswa setelah diberikan perlakuan (posttest). Sedangkan teknik non tes digunakan untuk mengukur sikap ilmiah siswa.

Teknik Analisis Data

Analisis data menggunakan (1) statistik deskriptif untuk mendeskripsikan data pengetahuan, keterampilan proses dasar dan sikap ilmiah; dan (2) statistik inferensial dengan menggunakan independent sampel t-test untuk menguji hipotesis penelitian pada taraf signifikansi $5 \%(\alpha=0,05)$.

\section{Hasil Penelitian dan Pembahasan}

Pembelajaran IPA di setiap jenjang pendidikan tentu memiliki tujuan dan target yang ingin dicapai. Menurut Howe \& Jones, pada jenjang sekolah dasar pembelajaran IPA bertujuan untuk mengembangkan dan memelihara keingintahuan tentang dunia sekitar, mengamati dan menjelajahi lingkungan dan pengalaman, mengembangkan keterampilan teknis 
dan intelektual yang dibutuhkan, membangun pengalaman dasar untuk memahami konsep penting dalam IPA serta menghubungkan apa yang dipelajari di sekolah dengan kehidupan sehari-hari (1993, p.17). Tujuan pembelajaran IPA ini mencakup berbagai aspek yakni aspek intelektual, proses dalam memperoleh pengetahuan, sikap dan aplikasi. Hal ini sesuai dengan karakteristik pembelajaran IPA yang mencakup pengetahuan, keterampilan proses, sikap dan penerapan.

Penelitian ini ingin mengkaji model pembelajaran 4-E learning cycle yang secara teoritis mampu mengembangkan aspek-aspek dalam pembelajaran IPA. Penelitian ini bermaksud untuk menguji model 4-E learning cycle terhadap pengetahuan, keterampilan proses dasar dan sikap ilmiah IPA siswa.

Kegiatan penelitian dilaksanakan di SD Katholik Kererobbo pada siswa kelas V semester II tahun pelajaran 2012/2013. Kegiatan ini berlangsung pada tanggal 21 Januari sampai tanggal 16 Februari 2013 dan sesuai dengan rancangan dalam persiapan mengajar yakni 8 kali pertemuan untuk kegiatan pembelajaran dan 2 pertemuan untuk pretest dan posttest. Kelas V yang dijadikan sebagai sampel penelitian terdiri dari 3 rombongan belajar yakni VA, VB dan VC.

Sebelum melaksanakan penelitian, dilakukan pretest pada kedua kelompok sampel untuk mengetahui kondisi awalnya. Pretest ini berupa tes terintegrasi untuk mengukur pengetahuan dan keterampilan proses dasar IPA serta pengisian angket skala sikap untuk mengukur sikap ilmiah.

Berdasarkan data uji $\mathrm{t}$ skor pretest dapat disimpulkan bahwa tidak terdapat perbedaan yang signifikan antara kelompok eksperimen dan kelompok kontrol. Hal ini dapat dilihat pada nilai signifikansi yang lebih besar dari 0,05. Data rangkuman hasil uji $\mathrm{t}$ skor pretest dapat dilihat pada Tabel 1.

Tabel 1. Rangkuman Uji t Skor Pretest

\begin{tabular}{lccc}
\hline \multicolumn{1}{c}{ Variabel } & t & df & sig \\
\hline Pengetahuan IPA & 0,739 & 61 & 0,463 \\
Keterampilan Proses Dasar & 1,011 & 61 & 0,316 \\
IPA & 0,151 & 61 & 0,881 \\
Sikap Ilmiah & & &
\end{tabular}

Setelah mengetahui bahwa kondisi kedua kelompok sampel adalah tidak berbeda secara signifikan, maka langkah selanjutnya adalah memberikan perlakuan dimana pada kelas eksperimen dilaksanakan pembelajaran IPA dengan model 4-E learning cycle sedangkan dikelas kontrol pembelajaran IPA menggunakan model pembelajaran ekspositori dengan materi pokok "Gaya".

Pada akhir kegiatan dilakukan posttest untuk mengetahui pengaruh model pembelajaran yang digunakan terhadap pengetahuan, keterampilan proses dasar dan sikap ilmiah.

Berdasarkan hasil pretest dan posttest yang telah dilakukan maka dapat dibuatkan rangkuman perbandingan rata-rata skor pretest posttest pada masing-masing variabel pada kedua kelompok sampel yang disajikan dalam Tabel 2.

Tabel 2. Perbandingan Rerata Skor PretestPosttest

\begin{tabular}{lcccc}
\hline \multirow{2}{*}{ Variabel } & \multicolumn{3}{c}{ Kelompok Sampel } \\
\cline { 2 - 5 } & \multicolumn{2}{c}{ Eksperimen } & \multicolumn{2}{c}{ Kontrol } \\
\cline { 2 - 5 } & Pre & Post & Pre & Post \\
\hline Pengetahuan & 7,37 & 13,44 & 8,22 & 11,97 \\
IPA & & & & \\
Keterampilan & 3,78 & 7,28 & 4,16 & 5,87 \\
Proses Dasar & & & & \\
Sikap Ilmiah & 104,59 & 117,25 & 104,77 & 111,00 \\
\hline
\end{tabular}

Data pada Tabel 2 menunjukkan bahwa rata-rata skor pada masing-masing variabel mengalami peningkatan setelah kedua kelompok sampel dikenai perlakuan. Pada variabel pengetahuan IPA, kelompok eksperimen mengalami peningkatan skor sebesar 6,07 sedangkan kelompok kontrol mengalami peningkatan sebesar 3,75. Pada variabel keterampilan proses dasar IPA, kelompok eksperimen mengalami peningkatan skor sebesar 3,50 sedangkan pada kelompok kontrol sebesar 1,62. Pada variabel sikap ilmiah, kelompok eksperimen mengalami peningkatan skor sebesar 12,66 sedangkan pada kelompok kontrol sebesar 6,23.

Berdasarkan deskripsi tersebut maka dapat disimpulkan bahwa pada masing-masing variabel, kelompok eksperimen yang mengimplementasikan model pembelajaran 4-E learning cycle mengalami peningkatan rerata skor yang lebih tinggi dibandingkan dengan kelas kontrol yang mengimplementasikan pembelajaran ekspositori. Untuk mengetahui besaran dan klasifikasi peningkatan skor pada masing-masing kelompok dan variabel, maka diperlukan perhitungan peningkatan rerata normal (average normalize gain) seperti yang dikemukakan oleh Hake (1997, p.65) dengan rumus sebagai berikut:

$$
\begin{aligned}
& \langle\mathrm{g}\rangle=\%<\mathrm{G}>/ \%<\mathrm{G}\rangle_{\max } \\
& \left.=\left(\%<\mathrm{S}_{\mathrm{f}}>-\%<\mathrm{S}_{\mathrm{i}}>\right) / 100-\%<\mathrm{S}_{\mathrm{i}}>\right)
\end{aligned}
$$


dimana $\mathrm{S}_{\mathrm{f}}$ dan $\mathrm{S}_{\mathrm{i}}$ merupakan rerata kelas dari pretest dan posttes. Formulasi tersebut dapat disederhanakan sebagai berikut :

$\langle\mathrm{g}\rangle=\underline{\text { Rerata skor posttest }- \text { Rerata skor pretest }}$

Skor maksimal - Rerata skor pretest

Berdasarkan rumus tersebut kemudian diklasifikasikan dalam tiga kategori yakni :
$(<\mathrm{g}\rangle)>0.7$
: Tinggi
$0.7>(<\mathrm{g}>)>0.3$
: Sedang
$(<\mathrm{g}>)<0.3$.
: Rendah

Gain Kelas Eksperimen

Gain Pengetahuan IPA

$\langle\mathrm{g}\rangle=(13,44-7,37) /(23-7,37)=0,388$

Gain Keterampilan Proses Dasar IPA

$\langle\mathrm{g}\rangle=(7,28-3,78) /(14-3,78)=0,342$

Gain Sikap Ilmiah

$\langle\mathrm{g}\rangle=(117,25-104,59) /(127-104,59)=0,564$

Gain Kelas Kontrol

Gain Pengetahuan IPA

$\langle\mathrm{g}\rangle=(11,97-8,22) /(23-8,22)=0,253$

Gain Keterampilan Proses Dasar IPA

$\langle\mathrm{g}\rangle=(5,78-4,16) /(14-4,16)=0,173$

\section{Gain Sikap Ilmiah}

$\langle\mathrm{g}\rangle=(111,00-104,77) /(127-104,77)=0,280$

Perhitungan gain pada kedua kelompok sampel diperoleh data bahwa pada kelompok eksperimen, peningkatan rerata normal pada variabel pengetahuan, keterampilan proses dasar dan sikap ilmiah IPA masing-masing adalah sebesar 0,$388 ; 0,342$; dan 0,564 dan semuanya berada pada klasifikasi sedang. Sedangkan pada kelompok kontrol, peningkatan rerata normal pada variabel pengetahuan, keterampilan proses dasar dan sikap ilmiah IPA masing-masing adalah sebesar 0,$253 ; 0,173$; dan 0,280 dan semuanya berada pada klasifikasi rendah. Berdasarkan data ini maka dapat disimpulkan bahwa kelompok eksperimen yang menggunakan pembelajaran siklus belajar 4-E mengalami peningkatan rerata skor yang lebih tinggi dibandingkan dengan kelas kontrol yang menggunakan pembelajaran ekspositori.

Kesimpulan ini diperkuat dengan data uji t skor posttest. Rangkuman data uji t skor posttest pada setiap variabel dapat dilihat pada Tabel 3 berikut :

Tabel 3. Rangkuman Uji t Skor Posttest

\begin{tabular}{lccc}
\hline \multicolumn{1}{c}{ Variabel } & t & df & Sig \\
\hline Pengetahuan IPA & $-2,056$ & 61 & 0,044 \\
Keterampilan Proses & -2.385 & 61 & 0,020 \\
Dasar IPA & $-4,849$ & 61 & 0,000 \\
Sikap Ilmiah &
\end{tabular}

Berdasarkan data pada Tabel 3 dapat diketahui bahwa nilai signifikansi variabel pengetahuan IPA, keterampilan proses dasar IPA, dan sikap ilmiah secara berturut-turut adalah 0,$044 ; 0,020$; dan 0,000 . Nilai signifikansi ini ternyata lebih kecil dari $\alpha$ yang telah ditetapkan yaitu 0,05 sehingga dapat disimpulkan bahwa pada tiap variabel, rerata kelompok eksperimen terbukti lebih tinggi secara signifikan dibandingkan kelompok kontrol. Hal ini juga membuktikan bahwa penerapan model 4-E learning cycle berpengaruh terhadap pengetahuan, keterampilan proses dasar dan sikap ilmiah siswa di sekolah dasar.

Martin et al. (2005, p.187) mengungkapkan bahwa siklus belajar 4-E menghasilkan peningkatan yang signifikan dalam prestasi siswa, keterampilan-keterampilan serta sikap ilmiah siswa. Hal ini disebabkan karena pembelajaran siklus merupakan cara berpikir dan bertindak yang konsisten dengan bagaimana siswa secara natural melakukan penyelidikan dan penemuan.

Banyak hasil penelitian yang mendukung penelitian ini seperti berikut: yang dilakukan oleh Yilmaz dan Cavas (2006). Penelitian ini bertujuan untuk mengetahui kefektifan metode siklus belajar 4-E terhadap tingkat pemahaman siswa kelas 6 dalam materi "Listrik" dan sikap mereka terhadap IPA. Hasil penelitian menunjukkan bahwa terdapat perbedaan yang signifikan antara dua kelompok pada posttes dimana nilai $\mathrm{p}<0,05$. Ini menunjukkan bahwa pengajaran dengan metode siklus belajar 4E lebih sukses dibandingkan dengan pengajaran tradisional. Selain itu juga disimpulkan bahwa terdapat perbedaan statistik yang signifikan antara rerata skor skala sikap terhadap IPA pada kelompok yang diajarkan dengan metode siklus belajar 4-E dan metode tradisional. Metode siklus belajar tidak hanya meningkatkan pencapaian siswa tetapi juga mengubah sikap mereka terhadap IPA.

Hasil penelitian Oren \& Ramasan (2008) menyimpulkan bahwa pembelajaran pada kelompok eksperimen yang menggunakan 
siklus belajar menghasilkan sikap positif terhadap IPA yang signifikan dibandingkan dengan kelompok kontrol yang menggunakan pembelajaran tradisional. Perbedaan ini secara statistik cukup signifikan dimana nilai $\mathrm{F}_{1-50,0,05}$ $=28,920 ; \mathrm{p}<0,05$.

Penelitian yang dilakukan oleh Ahmed. O. Qarareh. (2012) bertujuan untuk menyelidiki pengaruh penggunaan strategi siklus belajar dalam pengajaran terhadap prestasi IPA siswa kelas VI. Hasil penelitian menyimpulkan bahwa penggunaan siklus belajar mempunyai pengaruh yang sangat besar terhadap prestasi akademik. Peneliti merekomendasikan agar siklus belajar seharusnya digunakan dalam pengajaran IPA.

Penelitian Haryono (2006) menyimpulkan bahwa model pembelajaran berbasis keterampilan proses IPA terbukti cukup efektif dalam meningkatkan kemampuan proses IPA siswa sekaligus pencapaian hasil belajarnya secara keseluruhan. Tingkat pencapaian penguasaan konsep IPA, penguasaan proses IPA, dan sikap ilmiah IPA siswa yang memperoleh treatment pembelajaran berbasis keterampilan proses, masing-masing adalah 66,35\%, 67,27\%, dan $69,92 \%$. Khusus untuk penguasaan proses IPA dengan diterapkannya model ini telah dapat meningkatkan pencapaian siswa menjadi $67.27 \%$ dari kondisi sebelumnya yang baru $46.08 \%$.

Selain itu, hasil penelitian Oren \& Ramazan juga menyimpulkan bahwa "learning cycle approach can be used to increase students' positive attitudes toward science on elementary science education". Berdasarkan hasil analisis data dalam penelitian ini, maka dapat disimpulkan bahwa pembelajaran IPA dengan menggunakan model 4-E learning cycle berpengaruh terhadap pengetahuan, keterampilan proses dasar dan sikap ilmiah IPA siswa dibandingkan dengan pembelajaran ekspositori.

\section{Simpulan dan Saran}

Simpulan

Berdasarkan hasil analisis data dan pembahasan, maka dapat disimpulkan bahwa (1) Penerapan model 4-E learning cycle berpengaruh secara positif dan signifikan terhadap pengetahuan IPA siswa di SDK Kererobbo. (2) Penerapan model 4-E learning cycle berpengaruh secara positif dan signifikan terhadap keterampilan proses dasar IPA siswa di SDK Kererobbo. (3) Penerapan model 4-E learning cycle berpengaruh terhadap secara positif dan signifikan sikap ilmiah siswa di SDK Kererobbo.

Saran

Berdasarkan hasil penelitian dan kesimpulan, peneliti menyarankan: (1) Kepada pendidik pada jenjang sekolah dasar agar dapat menggunakan model pembelajaran yang dapat mengakomodasi berbagai aspek dalam pembelajaran IPA sehingga pembelajaran tidak hanya berorientasi pada aspek pengetahuan saja tetapi juga aspek keterampilan proses dan sikap ilmiah serta aplikasinya dalam kehidupan sehari-hari. Salah satu model pembelajaran yang dapat digunakan adalah model 4-E learning cycle. Namun penggunaan model ini tentu harus disesuaikan dengan karakteristik materi dan tujuan pembelajaran yang ingin dicapai. (2) Kepada peneliti yang ingin melakukan penelitian sejenis agar memaksimalkan setiap tahapan yang ada terutama pada tahap evaluasi sehingga mampu mencapai hasil belajar yang optimal. (3) Dalam penelitian lanjutan, peneliti perlu mengembangkan instrumen pedoman observasi guna mengukur aspek keterampilan proses dasar IPA yang ditinjau dari segi keterampilan teknis atau technical skill.

\section{Daftar Pustaka}

Depdiknas. (2006a). Peraturan menteri pendidikan nasional nomor 22 tahun 2006 tentang standar isi

Lawson, A.E. (1989). Teaching inquiry science in middle and secondary schools. USA: Narst Monograph

Martin, R. et al. (2005). Teaching science for all children : Inquiry method for contructing understanding-3 Ed. New York: Pearson Education.

Oren, F.S. \& Ramasan T. (2009). The effecttiveness of the learning cycle approach on learners' attitude toward science in seventh grade science classes of elementary school. Diambil pada tanggal 29 September 2012, dari http://www.ilko-gretimonline.org.tr/ 
Sugianto, Agus, dkk. (2009). Pembelajaran SAINS MI. edisi pertama. Learning Assistance Program for Islamic School (LAPIS).

Sulistyorini, Sri. (2007). Model pembelajaran SAINS sekolah dasar dan penerapannya dalam KTSP. Semarang: Tiara Wacana

Turkmen, H. (2006). How should science be thaught by using learning cycle approach in elementary school?. Diambil pada tang- gal 29 September 2012, dari http://www.ilkogretim-online.org.tr/

Yilmaz, H. \& Pinar H. C. (2006). The effect of the 4-E learning cycle method on students' understanding of electricity. vol 3. Diambil pada tanggal 2 Juli 2012, dari http://www.tused.org. 